ISSN 1420-3049

http://www.mdpi.org/

\title{
Synthesis and Catalytic Activity of Two New Cyclic Tetraaza Ligands
}

\section{María Hechavarría Fonseca, Thomas Hjelmgaard a and Burkhard König *}

Institut für Organische Chemie, Universität Regensburg, D-93040 Regensburg, Germany, Fax: (+49) 941-943-1717.

${ }^{a}$ Current address: Department of Chemistry, Technical University of Denmark, Denmark

* Author to whom correspondence should be addressed; e-mail: burkhard.koenig@chemie.uniregensburg.de

Received: 11 April 2003; in revised form: 9 May 2003 / Accepted: 9 May 2003 / Published: 31 May 2003

\begin{abstract}
Two new chiral cyclic tetraaza ligands were synthesized and characterized. Their catalytic activity was tested in the asymmetric addition of diethylzinc to benzaldehyde. The expected secondary alcohol was obtained in moderate yields, but with very low enantioselectivity.
\end{abstract}

Keywords: Chiral tetraaza ligands; asymmetric catalysis.

\section{Introduction}

The importance of nitrogen-containing ligands as catalysts for many asymmetric transformations has grown in the last years [1] because of their high stability, easy preparation and promising results [2]. In 1969 Uhlemann developed the synthesis of a new chiral Schiff base 1 from $o$-aminobenzaldehyde and 1,2-cyclohexanediamine [3]. Compounds containing this optically active transcyclohexane-1,2-diamine moiety have proven to be very useful in both asymmetric synthesis [4] and diastereomeric recognition of peptides [5]. 
We report in this paper the synthesis and characterization of two new tetraaza ligands containing 1,2-cyclohexanediamine as the chiral unit and their ability to catalyse the addition of diethylzinc to benzaldehyde.

\section{Results and Discussion}

The ligand $\mathbf{2}$ was synthesized from compound $\mathbf{1}$ by reaction with oxalyl chloride in THF in the presence of $\mathrm{Et}_{3} \mathrm{~N}$ as catalyst, according to a procedure reported in the literature [6] (Scheme 1). After flash chromatography of the crude product, the cyclic compound 2 was obtained in a $68 \%$ yield as colorless crystals.

\section{Scheme 1}

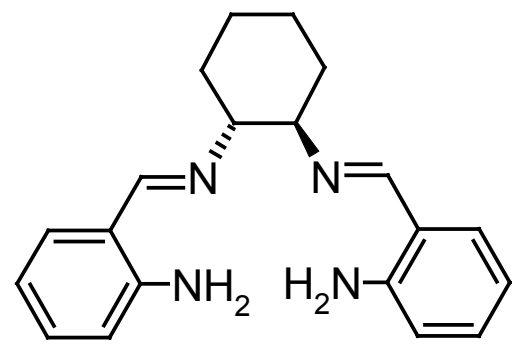

1

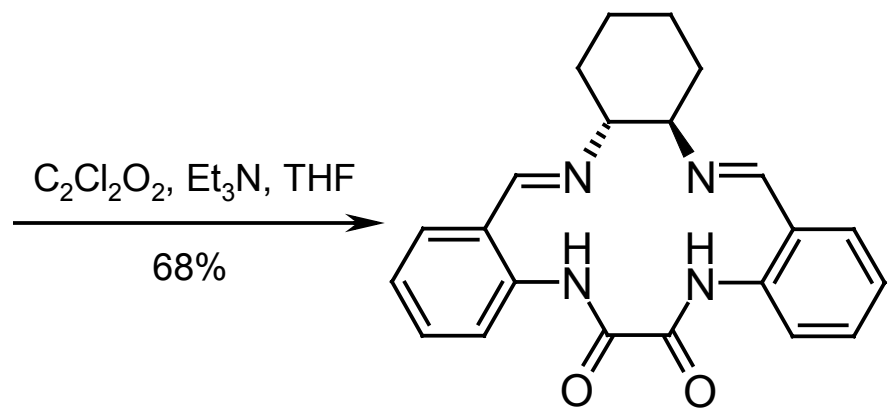

2

The synthesis of ligand $\mathbf{4}$ using $\mathbf{1}$ as starting material was attempted by reaction with di-tert-butyl dicarbonate $\left(\mathrm{Boc}_{2} \mathrm{O}\right)$ in $\mathrm{CH}_{2} \mathrm{Cl}_{2}$ using 4-dimethylaminopyridine (DMAP) as catalyst. Such reactions for similar substrates have been reported to give yields of 87-96\% [7]. According to the mechanism shown in Scheme 2, an intermediate urethane $\mathbf{B}$ is formed by reaction of the amine nitrogen with the $\mathrm{Boc}_{2} \mathrm{O}$. Intramolecular nucleophilic addition of the second arylamine to the urethane or an isocyanate, which may evolve from $\mathbf{B}$ by elimination of tert-butanol should yield urea 4 .

After performing the reaction and successive chromatographic separations, a colorless product was obtained. This product, however, displays in its ${ }^{13} \mathrm{C}$-NMR spectrum two carbonyl group signals at $\delta=151.3$ and $\delta=151.7$, while only one was expected. ${ }^{1} \mathrm{H}-\mathrm{NMR}$ spectra and mass spectrometry (molecular ion $\mathrm{m} / \mathrm{z}=391$ ) indicated a different product with structure 3. A likely mechanism for its formation is the reaction of $\mathbf{1}$ with $\mathrm{Boc}_{2} \mathrm{O}$ and loss of tert-butanol to $\mathbf{A}$ followed by intramolecular cyclization to yield 3. Only a few reports of stable carbamic anhydrides exist in the literature [8]. The proton and carbon NMR spectra of $\mathbf{3}$ indicate a non $\mathrm{C}_{2}$ symmetric conformation of the molecule. The ${ }^{1} \mathrm{H}-{ }^{13} \mathrm{C}$ HMBC NMR data show that each N-H group can be correlated to one CO carbon.

It was thought that upon heating compound 3, it would release $\mathrm{CO}_{2}$, thus leading to 4 . This was tested by differential scanning calorimetry (DSC) [9], which showed a reaction of $\mathbf{3}$ at $259{ }^{\circ} \mathrm{C}$, which indeed led to a loss of weight corresponding to $\mathrm{CO}_{2}$ elimination, however, the high temperature at which this reaction occurs makes it of limited synthetic interest [10]. 
Scheme 2

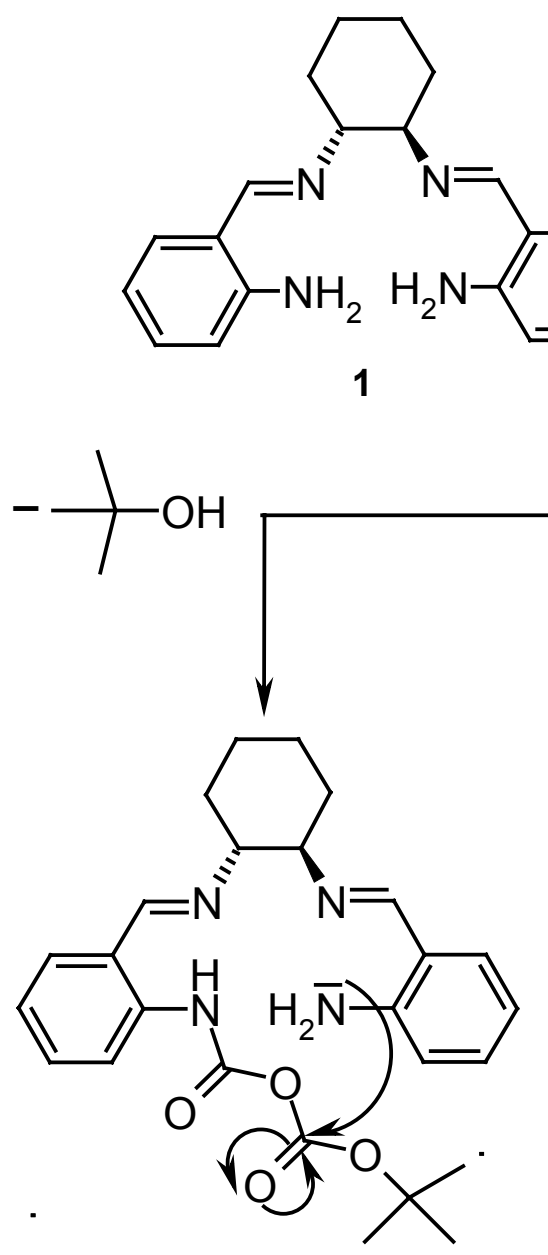

A

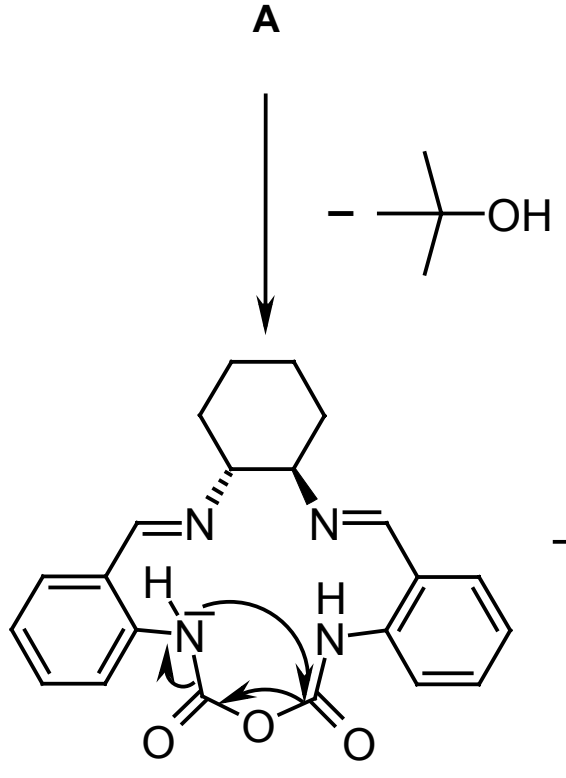

3

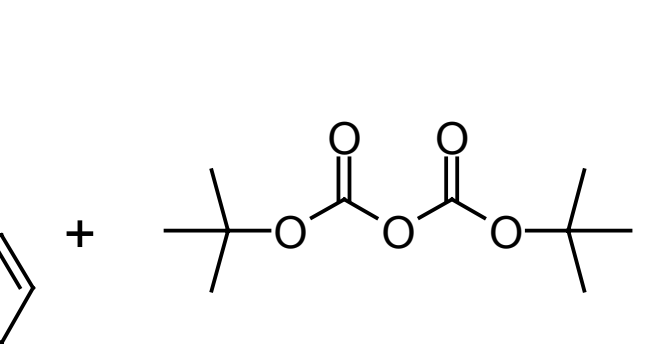

$-1 \mathrm{O}^{\mathrm{O}} \mathrm{OH}$

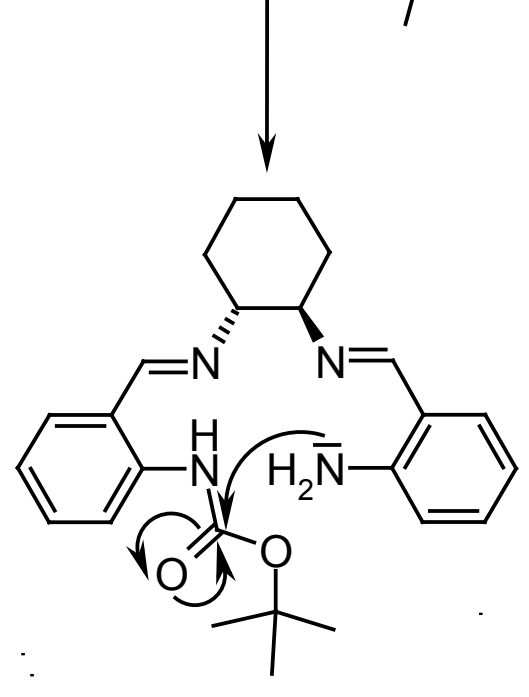

B

$-\frac{1}{1} \mathrm{OH}$

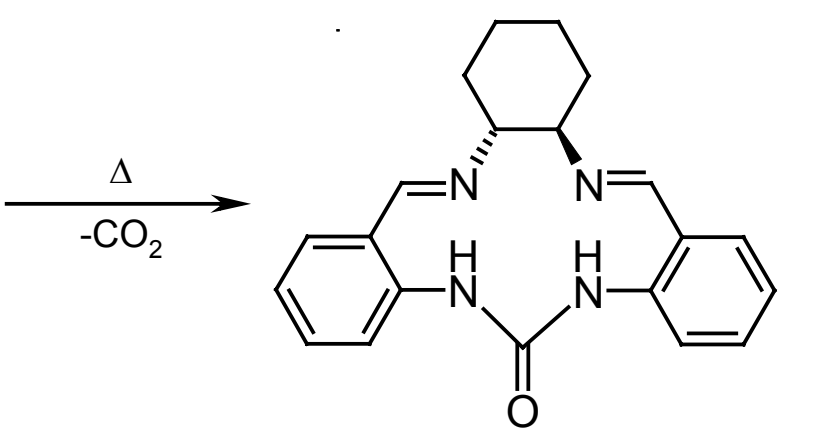

4 


\section{Catalysis}

The cyclic diimine ligands $\mathbf{2}$ and $\mathbf{3}$ were examined as catalysts for the asymmetric addition of diethylzinc to benzaldehyde (Scheme 3).

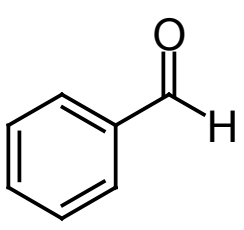

5
Scheme 3

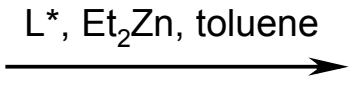

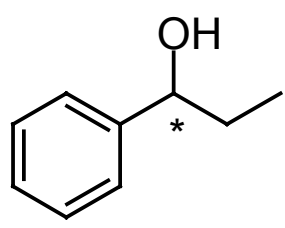

6

Moderate yields (51 and $88 \%$, respectively) of 1-phenylpropanol (6) were obtained, but no or very low enantioselectivities were observed [11]. The possible cause of these low selectivities could be the small size of the available cavity, which is not large enough to accommodate the $\mathrm{Zn}$ atom to form the intermediate zincate essential for the intramolecular alkyl transfer reaction.

\section{Experimental}

\section{General}

Melting points were determined with a Büchi SMP 20 and are uncorrected. IR-spectra were recorded with a Bio-Rad FTS $3000 \mathrm{MX}$ FT-IR. ${ }^{1} \mathrm{H}-\mathrm{NMR}$ and ${ }^{13} \mathrm{C}-\mathrm{NMR}$ were recorded with a Bruker ARX 400 or a Bruker AC 250 instruments at 250 and $62.9 \mathrm{MHz}$, respectively. The ${ }^{1} \mathrm{H}$ chemical shifts are reported in $\delta(\mathrm{ppm})$ relative to $\mathrm{CDCl}_{3}(7.26 \mathrm{ppm})$, DMSO- $\mathrm{d}_{6},(2.49 \mathrm{ppm})$ and TMS (0 ppm), while ${ }^{13} \mathrm{C}$ chemical shifts are reported in $\delta(\mathrm{ppm})$ relative to $\mathrm{CDCl}_{3}(77 \mathrm{ppm}), \mathrm{DMSO} \mathrm{d}_{6}(36.9 \mathrm{ppm})$ and TMS (0 ppm). MS-spectra were recorded on a Varian CH-5 (EI) and a Finnigan MAT SSQ 7000 (ESI). Solvents were distilled and dried according to standard laboratory methods [12].

\section{Synthesis of the ligands}

7,10-Cyclooxalamide- $N, N^{\prime}$-bis-(phenyl-2-ylmethylene)-cyclohexane-1R,2R-diamine (2): Schiff base 1 $(400 \mathrm{mg}, 1.25 \mathrm{mmol})$ and dry $\mathrm{Et}_{3} \mathrm{~N}(0.35 \mathrm{ml}, 2.51 \mathrm{mmol})$ were dissolved in dry THF $(20 \mathrm{~mL})$ under nitrogen with stirring. A solution of oxalyl chloride $(0.15 \mathrm{ml}, 1.77 \mathrm{mmol})$ in dry THF $(25 \mathrm{~mL})$ was added with a syringe pump over a period of $2.5 \mathrm{~h}$. The reaction mixture was then stirred for $19 \mathrm{~h}$ at room temperature. The mixture was concentrated to half of its volume and the colourless precipitate of the product was filtered off. Flash chromatography of the raw product in $\mathrm{CHCl}_{3}$ afforded the cyclic compound 2 (318 mg, $0.85 \mathrm{mmol}, 68 \%), \mathrm{mp}=223-225{ }^{\circ} \mathrm{C}\left(\right.$ dec.); $[\alpha]_{\mathrm{D}}^{25}=-17^{\circ}\left(c \quad 1.0, \mathrm{CHCl}_{3}\right)$; IR $(\mathrm{KBr}): v=3440,2963,2925,2854,2359,1683$, 1635, 1577, 1506, 1440, 1290, 1261, 1159, 1093, 
1025, 939, 859, 802, $753 \mathrm{~cm}^{-1} ;{ }^{1} \mathrm{H}-\mathrm{NMR}\left(\mathrm{CDCl}_{3}\right): \delta=1.53-2.13(\mathrm{~m}, 8 \mathrm{H}), 3.79(\mathrm{~s}, 2 \mathrm{H}), 7.00(\mathrm{dd}, 2 \mathrm{H}$, $J=7.6 \mathrm{~Hz}), 7.18(\mathrm{~d}, 2 \mathrm{H}, J=7.6 \mathrm{~Hz}), 7.40(\mathrm{dd}, 2 \mathrm{H}, J=7.9,7.6 \mathrm{~Hz}), 8.52(\mathrm{~s}, 2 \mathrm{H}, \mathrm{HC}=\mathrm{N}), 8.87(\mathrm{~d}, 2 \mathrm{H}$, $J=7.9 \mathrm{~Hz}), 14.22(\mathrm{~s}, 2 \mathrm{H}, \mathrm{PhNH}) ;{ }^{13} \mathrm{C}-\mathrm{NMR}\left(\mathrm{CDCl}_{3}\right): \delta=24.38,33.1,73.59,119.95,122.75,123.52$, 130.75, 132.85, 138.57, 159.74, 163.24; MS (PI-EIMS) m/z (\%): $374.2(8)\left[\mathrm{M}^{+\bullet}\right], 228.2(22)\left[\mathrm{M}^{+\bullet}\right.$ $\mathrm{N}=\mathrm{CH}-\mathrm{Ph}-\mathrm{NHCO}], 147.1(100)$ [N=CH-Ph-NHCO $]$

7,10-Cyclodicarbonic-diamide- $N, N^{\prime}$-bis-(phenyl-2-ylmethylene)-cyclohexane-1R,2R-diamine (3): Ditert-butyl dicarbonate $\left(\mathrm{Boc}_{2} \mathrm{O}, 657 \mathrm{mg}, 3.01 \mathrm{mmol}\right)$, 4-dimethylaminopyridine (DMAP, $41 \mathrm{mg}$, $0.34 \mathrm{mmol})$ and Schiff base $1(500 \mathrm{mg}, 1.56 \mathrm{mmol})$ were dissolved with stirring in $\operatorname{dry} \mathrm{CH}_{2} \mathrm{Cl}_{2}$ $(10 \mathrm{~mL})$ under nitrogen. The reaction mixture was stirred for 30 minutes at room temperature and then at $40{ }^{\circ} \mathrm{C}$ for $6 \mathrm{~h}$. Evaporation of the solvent and crystallization of the residue from EtOH $(50 \mathrm{~mL})$ afforded crude 3 . After two purifications by column chromatography (eluting with AcOEt) a colorless product $(230 \mathrm{mg}, 0.59 \mathrm{mmol}, 38 \%)$ was obtained, $\mathrm{mp}=253-255^{\circ} \mathrm{C}\left(\mathrm{dec}\right.$ ) $;[\alpha]_{\mathrm{D}}^{25}=-20^{\circ}(\mathrm{c} 1.5$, DMSO); IR (KBr): $v=3413,3208,3062,2923,2856,1679,1608,1498,1463,1385,1296,1270$, 1227, 1157, 1139, 938, 794, $754 \mathrm{~cm}^{-1}$; ${ }^{1} \mathrm{H}-\mathrm{NMR}\left(\mathrm{DMSO}_{6}\right): \delta=1.31-1.45(\mathrm{~m}, 3 \mathrm{H}), 1.73-1.77(\mathrm{~m}$, $3 \mathrm{H}), 1.90-1.95(\mathrm{~m}, 1 \mathrm{H}), 2.63-2.67(\mathrm{~m}, 1 \mathrm{H}), 3.62-3.71(\mathrm{~m}, 1 \mathrm{H}), 5.04-5.09(\mathrm{~m}, 1 \mathrm{H}), 5.96(\mathrm{~s}, 1 \mathrm{H}, \mathrm{HC}=\mathrm{N})$, $6.51(\mathrm{~s}, 1 \mathrm{H}, \mathrm{HC}=\mathrm{N}), 6.79-7.16(\mathrm{~m}, 4 \mathrm{H}), 7.20-7.23(\mathrm{~m}, 3 \mathrm{H}), 7.29-7.32(\mathrm{~m}, 1 \mathrm{H}), 9.68(\mathrm{~s}, 1 \mathrm{H}, \mathrm{PhNH})$, $9.71(\mathrm{~s}, 1 \mathrm{H}, \mathrm{PhNH}) ;{ }^{13} \mathrm{C}-\mathrm{NMR}\left(\mathrm{DMSO}_{\mathrm{d}}\right): \delta=24.93,25.58,30.72,31.96,53.96,63.76,81.24,87.63$, $113.29,113.34,118.03,118.21,120.87,120.92,127.28,127.43,129.27,129.46,136.47,136.53$, 151.33, 151.67; MS (CI-MS) m/z (\%): $391.3(100)\left[\mathrm{MH}^{+\bullet}\right], 244.2(73),\left[\mathrm{MH}^{+\bullet}-\mathrm{N}=\mathrm{CH}-\mathrm{Ph}-\mathrm{NHCO}\right]$

Catalysis: Preparation of 1-Phenyl-1-propanol (6): The ligand (0.05 mmol, $5 \mathrm{~mol} \%)$ was dissolved in dry toluene $(6 \mathrm{~mL})$ under nitrogen, diethylzinc $(1.1 \mathrm{M}$ solution in toluene, $0.1 \mathrm{~mL}, 0.11 \mathrm{mmol})$ was added, and the mixture was allowed to stir for $1 \mathrm{~h}$ at room temperature, then cooled to $0{ }^{\circ} \mathrm{C}$ or maintained at room temperature. The remaining diethylzinc $(2.17 \mathrm{ml}, 2.39 \mathrm{mmol})$ was added slowly. After five minutes the aldehyde $(1 \mathrm{mmol})$ was added. The reaction was stirred until no more aldehyde was observed (TLC), then quenched with $2 \mathrm{M} \mathrm{HCl}(6 \mathrm{~mL})$. The layers were separated and the aqueous phase was extracted with $\mathrm{Et}_{2} \mathrm{O}(3 \times 10 \mathrm{~mL})$. The combined organic extracts were dried with $\mathrm{Na}_{2} \mathrm{SO}_{4}$, filtered and concentrated under reduced pressure. The product was purified by short path distillation to give the alcohol as colorless oil. $\mathrm{R}_{f}=0.32$ (hexane/ethyl acetate $\left.5: 1\right) .-[\alpha]_{\mathrm{D}}^{25}=+30.6(c=1.11$, $\left.\mathrm{CHCl}_{3}\right)$ for the $(R)$-enantiomer [13]; ${ }^{1} \mathrm{H}-\mathrm{NMR}\left(\mathrm{CDCl}_{3}\right): \delta=0.89\left(\mathrm{t}, 3 \mathrm{H}, J=7.5 \mathrm{~Hz}, \mathrm{CH}_{3}\right), 1.74-1.83$ (m, 2H, $\left.J=13.6,7.5,7.0 \mathrm{~Hz}, \mathrm{CH}_{2}\right), 2.46(\mathrm{~s}, \mathrm{OH}), 4.59(\mathrm{t}, 1 \mathrm{H}, J=7.0 \mathrm{~Hz}, \mathrm{CH}), 7.29-7.37(\mathrm{~m}, 5 \mathrm{H}$, ArH); GC Analysis: HP 5890 II Chromatograph, FID Detector $300{ }^{\circ} \mathrm{C}$, Injector Temperature $260{ }^{\circ} \mathrm{C}$, Column Restek Rt $\beta$ DEX cst, $30 \mathrm{~m}, 0.32 \mathrm{~mm}, 0.25 \mu \mathrm{m}$, Oven Temperature $85^{\circ} \mathrm{C}$, Carrier gas $\mathrm{H}_{2}$, Column Head Pressure 3 bar. Retention times: $24.36 \min (R), 26.45 \min (S)$

\section{References and Notes}

[1] Fache, F.; Schulz, E.; Tommasino, M.; Lemaire, M. Chem. Rev. 2000, 100, 2159-2231.

[2] Alcón, M. J.; Iglesias, M.; Sánchez, F.; Viani. I. J. Organomet. Chem. 2001, 634, 25-33. 
[3] Uhlemann, E.; Plath, M. Z. Chem. 1969, 9, 234-235.

[4] Trost, B. J. Am. Chem. Soc. 1997, 119, 7879-7880.

[5] Skog, K. Tetrahedron Lett. 1992, 33, 1751-1754.

[6] Lindauer, D.; Atzrodt, J.; Beckert, R.; Görls, H. Liebigs Ann. 1995, 199-201.

[7] Knölker, H.-J.; Braxmeier, T.; Schlechtingen, G. Synlett 1996, 502-504.

[8] a) Christie, C. C.; Kirby, G. W.; McGuigan, H.; Mackinnon, J.W. J. Chem. Soc. Perkin Trans. 1 1985, 2469-2473; b) Ye, Y.; Aulinger, K.; Arnold, N.; Spahl, W.; Steglich, W. Tetrahedron Lett. 1997, 38, 8013-8016; c) Wallace, E. G. U.S. Patent 4117153, 1978, 1978-09-26; d) Nilsson, J. L. G.; Sievertsson, H.; Dahlbom, R. Acta Chem. Scand. 1968, 22, 683-685; e) Sievertsson, H.; Nilsson, J. L. G. Acta Chem. Scand. 1970, 24, 939-945; f) Bogentoft, C.; Sievertsson, H. Acta Chem. Scand. 1972, 26, 4172-4174.

[9] A sample of $7.041 \mathrm{mg}$ of 3 was heated under $\mathrm{N}_{2}$ from 25 to $300{ }^{\circ} \mathrm{C}$ at a rate of $10{ }^{\circ} \mathrm{C} / \mathrm{min}$. The reaction set in at $259.1{ }^{\circ} \mathrm{C}$ and the sample lost $0.818 \mathrm{mg}$ in weight, which corresponds to the loss of $\mathrm{CO}_{2}$ (theoretically $0.794 \mathrm{mg}$ ).

[10] The preparative synthesis of $\mathbf{4}$ thus never succeeded. Possible alternate ways of obtaining this compound could be to react the tetraaza ligand 1 with urea while heating (Davis, T. L.; Underwood Jr., H. W. J. Am. Chem. Soc. 1922, 44, 2595-2604), with phosgene in benzene (Jones, L. W.; Root, F. B. J. Am. Chem. Soc. 1926, 48, 181-195), with diphosgene in dioxane (Cordier, D.; Coulet, P. R. J. Chem. Soc. Perkin Trans. 2 1994, 4, 891-894) or with carbon dioxide in the presence of a strong base or with methyl chloroformate and $\mathrm{Et}_{3} \mathrm{~N}$ in $\mathrm{CH}_{2} \mathrm{Cl}_{2}$ (Naito, R.; Takeuchi, M.; Morihira, K.; Hayakawa, M.; Ikeda, K.; Shibanuma, T.; Isomura, Y. Chem. Pharm. Bull. 1998, 43, 8, 1286-1294).

[11] While with ligand 2 the racemic alcohol was obtained, ligand 3 gave the $R$-isomer in $6 \%$ ee.

[12] a) Collective of authors, Organikum, 18. Edition; Deutscher Verlag der Wissenschaften: Berlin, 1990; pp. 638-659; b) Tietze, L. F.; Eicher, T. Reaktionen und Synthesen in organischchemischen Grundpraktikum, 2nd Edition; Georg Thieme Verlag: Stuttgart, 1991; pp. 547-551.

[13] Oriyama, T. Chem. Lett. 1984, 12, 2071-2074.

Sample availability: Samples of compounds $\mathbf{1}, \mathbf{2}$ and $\mathbf{3}$ are available from MDPI.

(C) 2003 by MDPI (http://www.mdpi.org). Reproduction is permitted for noncommercial purposes. 